Nevşehir Bilim ve Teknoloji Dergisi (2019), 8(2) 96-102

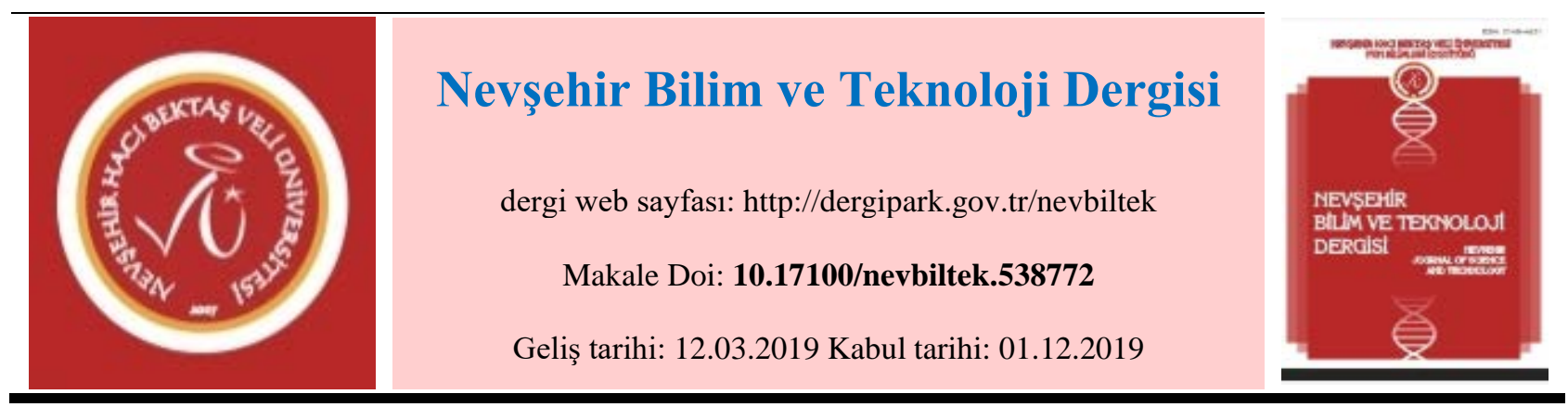

\title{
Some Physical Properties of the Building Stones from Elazıg-Nevsehir Region
}

\author{
Ayşe BICER \\ Fırat Üniversitesi Mühendislik Fakültesi Kimya Müh. Bölümü Elazığ \\ ORCID ID:0000-0003-4514-5644
}

\begin{abstract}
In this study, some physical properties of the Korpe and Zafran stones (Elazig), Yesilyurt stone (Malatya), Nemrut, Karadag and Ali dağ stones (Adiyaman) and Urgup stones (Nevsehir) which have been used extensively as a building material in cities and even in neighbour cities. Used as construction components, these stones are highly praised by the people living in those areas due to their ease of handling and convenient thermal characteristics. The objective here is to determine what kind of properties these stones had as a building material. With this objective, samples of stones from two different source were taken. After chemical analysis, the experiments for determining the heat conductivity and heat capacity, water absorption and mechanical strength were carried out. The results are compared with the other building materials especially in the aspects of energy saving, strength and natural comfort conditions.
\end{abstract}

Keywords: Korpe stone, Nemrut stone, Urgup stone, Yesilyurt stone, building material

\section{Elazığ - Nevşehir Bölgesinde Bulunan Yapı Taşlarının Bazı Fiziksel Özellikleri}

Öz

Bu çalışmada yedi yörede bulunan ve bina yapı malzemesi olarak kullanılan Körpe ve Zafran taşları (Elazı̆̆), Yeşilyurt taşı (Malatya), Nemrut, Karadağ ve Ali dağ taşları (Adıyaman) ve Ürgüp (Nevşehir) taşlarının bazı fiziksel özellikleri araştııılmıştır. Taşlar yörede bina yapı elemanı olarak kullanılmakta ve halk arasında işleme kolaylığı ve ısı özellikleri açısından övgü ile sözü edilmektedir. Amaç, bölgede çok kullanılan taşların, bina yapı elemanı olarak gerçekte ne tür özelliklere sahip olduğunu belirlemektir. Taşların fiziksel özelliklerini belirlemek üzere, her taş için iki ayrı taş ocağından numuneler alındı. Kimyasal analizden sonra, 1sı iletkenliğini ve 1sı kapasitesini, su emme oranı ve mekanik dayanım değerleri için deneyler gerçekleştirilmiştir. Sonuçlar, özellikle enerji tasarrufu, dayanıklılık ve doğal konfor koşulları açısından diğer yapı malzemeleri ile karşılaştırıldı.

Anahtar Kelimeler: Körpe taşı, Nemrut taşı, Ürgüp taşı, Yeşilyurt taşı, yapı malzemesi

\section{Giriş}

Energy costs, price escalation in building materials along with the demand growth towards housing bear the potential to make the regional stones as a building material a current issue. The stones are mostly used as carriers, but rarely as filling material, for which Karacadag stone of Diyarbakir, Sanliurfa stone and Ahlat stone from Bitlis can be sited as examples for these kind of stones [1, 2, 3, 4]. Focused on the economic aspects, this analysis may be inferred as

Sorumlu yazar e-mail: abicer@firat.edu.tr 
that the use of stones, which are within a certain distance to a quarry, would be more efficient compared to the fabricated building materials such as block brick, hollow brick, briquette.

Stones, which are under research for whether having the potential to be used as building material, can be easily cut with a saw just like a wood, once they are just removed from the quarry, during which period they conserve the moisture, along with being able to be drilled with a driller, dressed with hard objects and being nailed [5, 6, 7]. Such characteristics of the stones rendered them more popular as building materials in buildings that are constructed within the region.

In this study, thermal and mechanical properties of Korpe, Zafran, Yesilyurt, Karadag, Alidag and Urgup stones are examined. The stones have been used as carried building element in the region for many years, thus being recognized respected as a building element by people. It is not certain whether the use of such stones is popular due to the fact that it is a durable material, or it is easy to supply. This study aims at providing an insight on this matter.

\section{Materyal ve Metot}

Korpe Stone: Quarries are located in Korpe village, located $15 \mathrm{~km}$ to Elazig, having large reserves. These stones have been used as building materials for buildings, minaret, stairs, tombstone and paving works till today within the region. It is extremely resistant to high and low temperatures. It bears high amounts of moisture while being removed out of the quarry, thus being easy to process. The resistance increases after the moisture within is removed out.

Zafran Stone: The quarries that are located within the borders Elazig Municipality have large reserves. It is easy to remove the stone from the quarry and shape it. The stone has a greenish colour.

Yesilyurt Stone: Being removed from the quarries in Yesilyurt / Malatya, this stone is a sandstone type, categorized under sedimentary-stone class. This stone is hardened when exposed to fire. Having a brownish colour, it is frequently used for building bakery and construction of quarries in the region.

Nemrut Stone: The quarry is located in Kahta Country of Adiyaman. Categorized under organic sedimentary stone, it has a yellowish and whitish colour. With a hardness level of 3-4 mohs, it can be processed in terms of its physical properties. Unless it loses the moisture within after being removed from the quarry and it is exposed to chemical impact of the outer environment for a long this, this stone can be conveniently shaped and processed..

Karadag Stone: The quarries are located between Pirin river and Temruz village in the north of Adiyaman. It is mostly used as building material by the local community. Thanks to its high moisture level, it is quite easy to process. It is used in the making of briquette, in general.

Alidag Stone: The quarries are located between Terman village and Ziyaret river in the South of Adiyaman. With a high processability ratio thanks to its high moisture level, it is used as building material for construction of buildings.

Urgup Stone: Having large reserves in and around area of Urgup in Nevsehir, this is a whitish-yellow precipitation stone. It is widely used for construction works of masonry buildings in the region. It is quite easy to process the stone, as well.

As much they are currently used as building material, the stones are also used in many regions of Anatolia, as well. Chemical analysis results of the stones can be seen as a whole in Table 1.

Sample stones for both thermal tests and pressure \& abrasion tests were received - with the dimensions 150x60x20 mm and 100x100x100 mm, respectively - from two different quarries in the respective regions (Figure 1).

Table 1. The chemical composition of the samples (\%)

\begin{tabular}{cccccccc} 
& $\mathrm{SiO}_{2}$ & $\mathrm{Al}_{2} \mathbf{O}_{3}$ & $\mathbf{F e}_{2} \mathbf{O}_{3}$ & $\mathbf{C a O}$ & $\mathbf{M g O}$ & $\begin{array}{c}\text { Loss of } \\
\text { ignition }\end{array}$ & Undefined \\
Korpe (Elazig) & 5.05 & 0.31 & 0.30 & 52.34 & 0.82 & 40.84 & 0.34 \\
Zafran (Elazig) & 49.11 & 10.38 & 4.43 & 16.74 & 3.48 & 14.73 & 1.13 \\
Yesilyurt (Malatya) & 70.58 & 14.03 & 7.25 & - & - & 6.13 & 1.74 \\
\hline Nemrut (Adiyaman) & 46.80 & 18.45 & 16.20 & 12.23 & 4.88 & - & 1.44 \\
\hline Karadag (Adiyaman) & 0.62 & - & - & 56.64 & 0.85 & 40.85 & 1.04 \\
\hline Alidag (Adiyaman) & 0.93 & - & - & 56.07 & 0.83 & 40.75 & 1.42 \\
\hline Urgup (Nevsehir) & 8.10 & 2.15 & 1.38 & 48.25 & 1.58 & 38.36 & 0.18 \\
\hline
\end{tabular}


Nevşehir Bilim ve Teknoloji Dergisi (2019), 8(2) 96-102

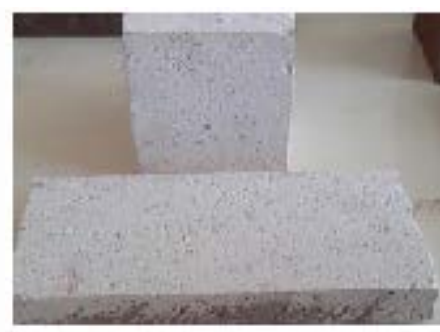

a)

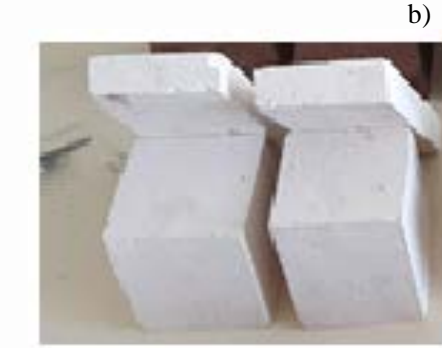

d)

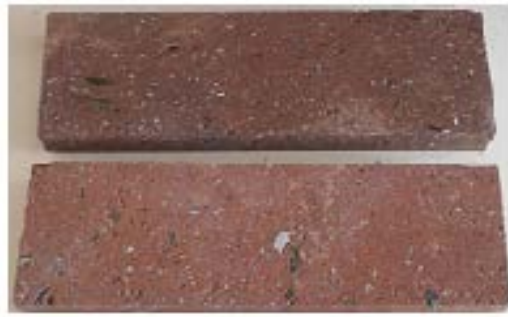

c)

Fig 1. Samples stones a) Korpe, b) Zafran, c) Yasilyurt, d) Urgup and Nemrut, e) Karadag

\subsection{Thermal conductivity, specific heat capacity and thermal diffusivity tests}

The measurement procedures were carried out with “Isomet 2104”, measuring in temporary regime and operating in hot-wire method. Measuring as per DIN 510406 norm, this device was used to carry out measurements from 3 different point on each and every sample under room temperature of $22-25{ }^{\circ} \mathrm{C}$, calculating the arithmetic mean of these 3 values (Figure 2). Thermal conductivity coefficient of the device has a tolerance of $5 \%$ between 0.02 to $6 \mathrm{~W} / \mathrm{mK}$. Volumetric specific heat capacity is measured with a tolerance ratio of $15 \%$ between $4.0 \times 10^{4}$ to $4.0 \times 10^{6} \mathrm{~J} / \mathrm{m}^{3} \mathrm{~K}$ [8, 9]. Measurement results are given in Table 2

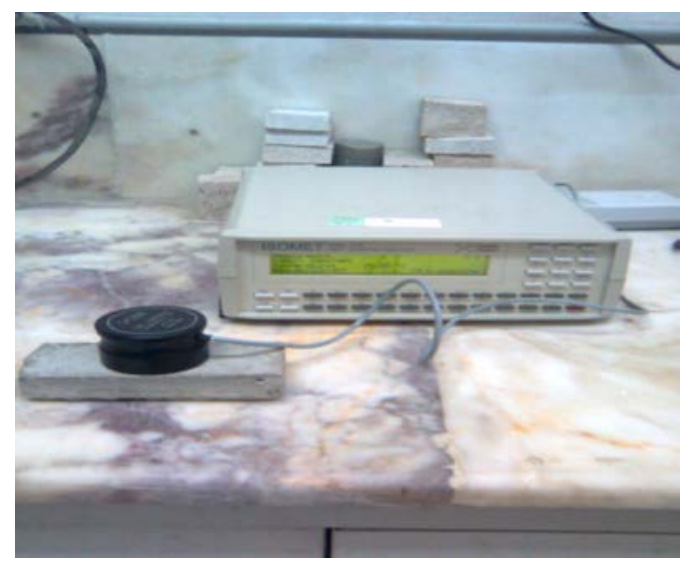

Fig 2. Isomet 2104 unit

\subsection{Compressive, Tensile Strengths and Volume Abrasion Tests}

Endurance tests were carried out on the samples in accordance with TS 699 standard [10]. Compressive strength tests for the samples were carried out with Ele International branded device, bearing the following features: $3000 \mathrm{kN}$ loading capacity; digital control panel; adjustable loading rate; applying uniaxial force. Compressive strength test results were translated into tensile strength with Eq. (1) according to TS 500 [11].

$$
f_{c t k}=0.35 \sqrt{f_{c k}}
$$

Where, $\mathrm{f}_{\mathrm{ck}}$ : compressive strength $\left(\mathrm{N} / \mathrm{mm}^{2}\right)$ and $\mathrm{f}_{\mathrm{ctk}}$ : tensile strength $\left(\mathrm{N} / \mathrm{mm}^{2}\right)$

Volume abrasion lost results for $88 \mathrm{rpm}$ within the scope of frictional abrasion tests (Böhme) can be seen in Table 3. 


\subsection{Water Absorption Test}

The objective of this test is to determine the presence of a dry volume, where the ice crystals within can expand, as the building materials -in direct contact with water- freeze [12, 13, 14, 15]. This feature ensures warranty for the material against freezing. The dry weight $\left(\mathrm{W}_{\mathrm{k}}\right)$ of each sample was determined. Then the water level is gradually raised within the water tank, where the samples are placed, adding water into the tank in a manner allowing the samples to be submerged. The change of the samples' weight based on time can be seen in Figure 3. After keeping the samples in the water for 48 hours, they were removed out of the water and wiped, finding the water-absorbed weight $\left(\mathrm{W}_{\mathrm{d}}\right)$, while on the other hand calculating the water absorption ratio with the Eq. 2.

$$
\text { Water absorption percent }=\left\{\left[\mathrm{W}_{\mathrm{d}}-\mathrm{W}_{\mathrm{k}}\right] / \mathrm{W}_{\mathrm{k}}\right\} \times 100
$$

\subsection{Drying Ratio}

The objective of drying ratio test is to analyze the breathing ability of the samples [16]. Kept in the water tank for 48 hours, the samples are removed out of the water and wiped with a damp cloth. Then, they are left to natural drying under $22^{\circ} \mathrm{C}$ of room temperature. The drying ratios in 24 hours were calculated with the Eq 3 . Since the drying process occurred via vaporization through the material surface, the water movement was seen via capillary channels from the bottom of the material to the surface. In other words, drying is achieved by removing the moisture from within by means of vapor permeability resistance (Figure 4).

$$
\text { Drying ratio }=\left\{\left[\mathrm{W}_{\mathrm{d}}-\mathrm{W}_{\mathrm{k}}\right] / \mathrm{W}_{\mathrm{d}}\right\} \times 100
$$

\subsection{Density Test}

Dry weights of the samples were taken with the weighing machine having a tolerance of $1 \%$, while the density levels were calculated by identifying the sample volumes.

\section{Results and Discussions}

Following the tests applied on these samples;

Korpe stone seems to have better results compared to the similar materials in Table 4, with thermal conductivity coefficient of $0.71 \mathrm{~W} / \mathrm{mK}$, diffusion coefficient of $2.54 \times 10^{-7} \mathrm{~m}^{2} / \mathrm{s}$ (Table 2). Moreover, it provides results that are close to the high-strength natural building stones considering its compressive strength of $52.6 \mathrm{~N} / \mathrm{mm}^{2}$ and tensile strength of $5.4 \mathrm{~N} / \mathrm{mm}^{2}$, having almost the same values with such artificial materials like concrete briquette, brick, gas-concrete. It's $1.2 \%$ of abrasion loss proves it durable (Table 3 )

While Zafran stone has better thermal conductivity of $0.74 \mathrm{~W} / \mathrm{mK}$, diffusion coefficient of $2.55 \times 10^{-7} \mathrm{~m}^{2} / \mathrm{s}$. compared to granite, sandstone, marble and limestone and close to the values for concrete, its diffusion coefficient is lower than these materials. Its compressive $\&$ tensile strength and abrasion values seem to be lower compared to Korpe stone. Having a water absorption ratio lower than $30 \%$ indicates that the stones can be used in humid environments [6, 8], leastwise having the ability to breath based on the review of drying rates (Figure 4).

Karadag stone seems to have better results with the thermal conductivity coefficient of $0.57 \mathrm{~W} / \mathrm{mK}$ and diffusion coefficient of $2.91 \times 10^{-7} \mathrm{~m}^{2} / \mathrm{s}$ compared to granite, marble, limestone and sandstone. Considering its compressive strength of $17.01 \mathrm{~N} / \mathrm{mm}^{2}$ and tensile strength of $1.44 \mathrm{~N} / \mathrm{mm}^{2}$, which are lower compared to the high-strength building stones, they are almost the same with artificial materials such as concrete, briquette, brick and gas-concrete. An abrasion loss of 2.35\% proves it usable as a building material for stairs and floor, which are exposed to extreme abrasion.

While Alidag stone is better than granite, sandstone, marble and limestone with a thermal conductivity coefficient of $1.31 \mathrm{~W} / \mathrm{mK}$, which, on the other hand, is close to the values for concrete, its diffusion coefficient is lower than some of these materials.

With a thermal conductivity coefficient of $0.75 \mathrm{~W} / \mathrm{mK}$, Nemrut mountain stone has better results compared to concrete, granite, marble and sandstone,

No significantly superior aspect was detected on Yesilyurt stone compared to similar building materials, in terms of energy saving.

With a thermal conductivity coefficient of $0.53 \mathrm{~W} / \mathrm{mK}$ and thermal diffusivity coefficient of $3.68 \times 10^{-7} \mathrm{~m}^{2} / \mathrm{s}$, Urgup stone seems to have better results compared to concrete, granite, marble and sandstone. Considering its compressive strength of $7.5 \mathrm{~N} / \mathrm{mm}^{2}$ and tensile strength of $0.8 \mathrm{~N} / \mathrm{mm}^{2}$, which are lower compared to the high-strength 
Nevşehir Bilim ve Teknoloji Dergisi (2019), 8(2) 96-102

building stones, they are almost the same with artificial materials such as concrete, briquette, brick and gas-concrete. Its abrasion loss of $12.9 \%$ renders the stone unusable as a building materials for stairs, floors, which are extremely exposed to abrasion.

It is a massive advantage for these stones to be processed more conveniently compared to a number of buildings materials, along with being suitable for electrical \& water installation conduits, drilling, cutting, dressing, nailing.

Given that the stones are cost-efficient, easy-to-procure, while having large reserves and better thermal characteristics, it is a motive to prefer the use of the same thanks to ensuring energy saving, while being used as a charge carrier element instead of brick or briquette.

\begin{tabular}{|c|c|c|c|c|}
\hline Materials & $\begin{array}{l}\text { Density } \\
\left(\mathbf{k g} / \mathrm{m}^{3}\right)\end{array}$ & $\begin{array}{c}\text { Thermal } \\
\text { conductivity } \\
\text { (W/mK) }\end{array}$ & $\begin{array}{c}\text { Specific heat } \\
\text { capacity } \\
\text { Cp(J/kgK) }\end{array}$ & $\begin{array}{c}\text { Thermal } \\
\text { diffusivity } \\
\text { a.10-7 }\left(\mathrm{m}^{2} / \mathrm{s}\right)\end{array}$ \\
\hline Korpe & 2690 & 0.71 & 1038 & 2.54 \\
\hline Zafran & 2773 & 0.74 & 1045 & 2.55 \\
\hline Yesilyurt & 1890 & 1.21 & 1068 & 5.68 \\
\hline Nemrut & 1385 & 0.75 & 972 & 5.57 \\
\hline Karadag & 1950 & 0.57 & 1003 & 2.91 \\
\hline Alidag & 2215 & 1.31 & 985 & 6.00 \\
\hline Urgup & 1485 & 0.53 & 968 & 3.68 \\
\hline Materials & $\begin{array}{c}\text { Compressive } \\
\text { strength } \\
\text { (Mpa) } \\
\end{array}$ & $\begin{array}{c}\text { Tensile strength } \\
\text { (Мра) }\end{array}$ & $\begin{array}{c}\text { Water } \\
\text { absorption (\%) }\end{array}$ & $\begin{array}{c}\text { Volume } \\
\text { abrasion } \\
(\%)\end{array}$ \\
\hline Korpe & 52.6 & 5.4 & 1.55 & 1.2 \\
\hline Zafran & 29.1 & 3.22 & 1.95 & 1.4 \\
\hline Yesilyurt & 11.1 & 1.15 & 8.6 & 13.1 \\
\hline Nemrut & 10.2 & 1.0 & 17 & 5.1 \\
\hline Karadag & 17.01 & 1.44 & 11.4 & 2.35 \\
\hline Alidag & 49.59 & 2.52 & 4.7 & 0.49 \\
\hline Urgup & 7.5 & 0.8 & 19.87 & 12.9 \\
\hline
\end{tabular}

\begin{tabular}{|c|c|c|c|c|}
\hline Materials & Density $\left(\mathrm{kg} / \mathrm{m}^{3}\right)$ & $\begin{array}{c}\text { Thermal } \\
\text { conductivity } \\
(\mathrm{W} / \mathrm{mK})\end{array}$ & $\begin{array}{c}\text { Specific heat } \\
\text { capacity } \\
\text { Cp(J/kgK) }\end{array}$ & $\begin{array}{c}\text { Thermal } \\
\text { diffusivity } \\
\text { a.10 }\left(\mathrm{m}^{2} / \mathrm{s}\right)\end{array}$ \\
\hline Concrete & 1906 & 0.814 & 879 & 4.91 \\
\hline Granite & 2643 & 1.73 & 816 & 13.15 \\
\hline Limestone & 2483 & 1.16 & 906 & 5.68 \\
\hline Sandstone & 2235 & 1.85 & 712 & 11.65 \\
\hline Marble & 2603 & 2.77 & 808 & 3.94 \\
\hline Common brick & 1602 & 0.692 & 837 & 5.16 \\
\hline
\end{tabular}

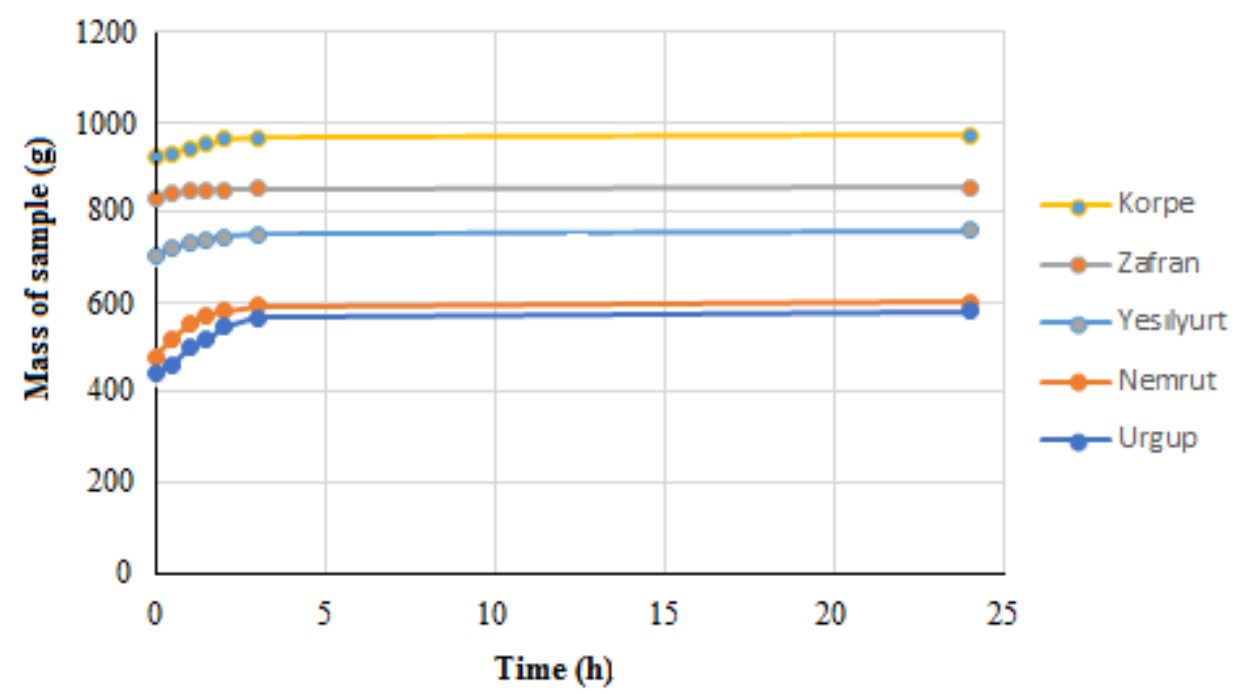

Fig 3. Mass change of samples in water absorption tests 


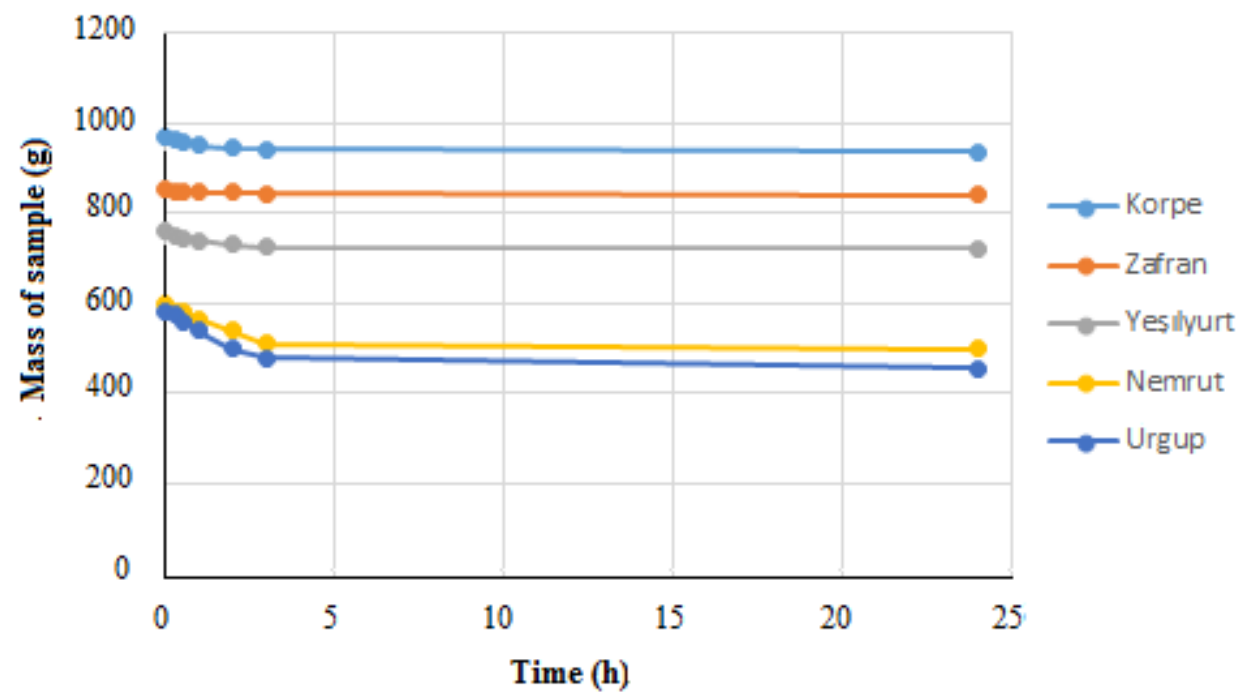

Fig 4. Mass change of samples in the drying test

\section{Conclusions}

Following the researches and tests carried out on the stones, which are accepted as a respected building material, thus being utilized by those living in the respective region, the following reasons are confirmed to be motive to prefer these stones in order for using these stones in the aforementioned regions:

$\checkmark \quad$ Having large reserves and available to be used for many years,

$\checkmark \quad$ It is a reason for preference with regards to these stones to be used instead of brick or briquette as load bearing elements in structures (i.e. buildings) due to having reserves in large amounts, being suitable to be used for many years, as well as being easy to procure, ensuring energy saving and lowering the costs.

Karadag and Urgup stones are used as load bearing for thermal comfort, while Korpe, Zafran and Nemrut stones are being used as load bearing, and Alidag and Yesilyurt stones is used as load bearing, and floor covering in the local buildings thanks to the thermal and mechanical properties of the stones.

$\checkmark \quad$ Having a water absorption ratio lower than 30\%, which indicates that the stones can be used in humid environments, leastwise having the ability to breath based on the review of drying rates.

For these stones, the above stated reasons are recognized as the motive to prefer for being used as building materials within the region and neighbouring provinces.

\section{Kaynaklar}

[1] Devecioglu A., G., “An Investigation on the Heat Conduction Parameters of Porous Building Stones”, Master Thesis, Firat University, 2001.

[2] Bicer Y., Yildiz C., "Pehlivan D. "Some Physical Properties of the Building Stones from Mardin and Its Districts”, TIEES-96 First Trabzon International Energy and Environment Symposium, July 29-31, Vol. 3, 1005 1009, July 29-31, Trabzon-Turkey,

[3] Bakış A., Işık E., Hattatoğlu F., “Akıllı A,. “Jeolojik Miras Nitelikli Ahlat Taşı'nın İnşaat Sektöründe Kullanımı”, III. Uluslararası Ahlat-Avrasya Bilim, Kültür ve Sanat Sempozyumu Bildiriler Kitabı (Editörler Doğru M. ve Aksoy E.), 46-59, 22-24 Eylül Ahlat- Bitlis 2014 
Nevşehir Bilim ve Teknoloji Dergisi (2019), 8(2) 96-102

[4] Akın M., Özvan A., Dinçer İ., Oyan V., “Tapan M. Ahlat Taşı’nın Atmosferik Etkiler Altındaki Duyarlılığı”, III Uluslararası Ahlat-Avrasya Bilim, Kültür ve Sanat Sempozyumu Bildiriler Kitabı (Editörler Doğru M. ve Aksoy E.), 60-69, 22-24 Eylül Ahlat- Bitlis 2014

[5] Gevrek A. İ., Kazancı N., “İnimbrit Oluşumu ve Özellikleri”, Jeoloji Mühendisliği Dergisi, 38, 39-42, Ankara 1991

[6] Kazancı N., Gürbüz A., “Jeolojik Miras Nitelikli Türkiye Doğal Taşları”, Türkiye Jeoloji Bülteni, 57, 1, 2014.

[7] Pivko D., “Natural Stones in Earth’s History”, Acta Geologica, 58, 73-86, 2003.

[8] Bicer Y., Devecioglu A.G, Akpinar E.K., Effective thermal conductivity of porous stones, Firat University Turkish Journal of Science \& Technology, 15(4), 613-622, 2004.

[9] Kaya A., Kar F., "Properties of Concrete Containing Waste Expanded Polystyrene and Natural Resin", Construction and Building Materials, 105, 572-578, 2016.

[10] TS 699, “The Test and Experiment Methods of Natural Building Stones”, TSE, Ankara, 1978

[11] TS 500, Turkish Standard, Ankara, 2000.

[12] Kaya A., Kar F., "Thermal and Mechanical Properties of Gypsum Plaster Mixed with Expanded Polystyrene and Tragacanth”, Thermal Science and Engineering Progress, 1, 59-65, 2017.

[13] Bicer A., Kar F., "The Effects of Apricot Resin Addition to the Light Weight Concrete with Expanded polystyrene”, Journal of Adhesion Science and technology, 31(21), 2335-2348, 2017.

[14] Bicer A., “Some Physical Properties of the Building Stones from Southeastern Anatolia Region”, Bartin University International Journal of Natural and Applied Sciences, 2(1):9-15, 2019.

[15] Dinçer İ., Özvan A., Akın M., Tapan M., Oyan, V., "İgnimbiritlerin Kapiler Su Emme Potansiyellerinin Değerlendirilmesi”: Ahlat Taşı örneği. Yüzüncü Yll Üniversitesi Fen Bilimleri Enstitüsü Dergisi, 17 (2), 64-71, 2012.

[16] “Yapı Malzeme ve Elemanları, Özellikleri-Kullanma Yöntemleri”, Ytong, İstanbul, 1985

[17] Toksoy M., “Endüstriyel Malzemelerin Isıl İletkenlik Katsayıları”, T.M.M.O. Mühendis ve Makine Dergisi, 347, 12-15, 1988 